\title{
Saline-water irrigation and plant growth regulator application on zucchini fruit yield and quality
}

\author{
Maria W. de L. Souza ${ }^{1}$, Salvador B. Torres ${ }^{1}$, Francisco de A. de Oliveira ${ }^{2}$, Isabelly C. da S. Marques ${ }^{3}$, \\ Kleane T. O. Pereira ${ }^{1} \&$ Ítala T. Guimarães ${ }^{3}$
}

${ }^{1}$ Universidade Federal Rural do Semi-Árido/Departamento de Ciências Agronômicas e Florestais/Programa de Pós-Graduação em Fitotecnia. Mossoró, RN, Brasil. E-mail: williane-lima@hotmail.com - ORCID: 0000-0001-6434-680x; sbtorres@ufersa.edu.br (Corresponding author) - ORCID: 0000-00030668-3327; kleane_rn@hotmail.com - ORCID: 0000-0002-3863-9606

${ }^{2}$ Universidade Federal Rural do Semi-Árido/Departamento de Ciências Agronômicas e Florestais/Programa de Pós-Graduação em Manejo de Solo e Água. Mossoró, RN, Brasil. E-mail: thikaoamigao@ufersa.edu.br - ORCID: 0000-0002-6895-7736

${ }^{3}$ Universidade Estadual Paulista “Júlio de Mesquita Filho"/Programa de Pós-Graduação em Agronomia/Faculdade de Ciências Agronômicas. Botucatu, SP, Brasil. E-mail: isabelly_cristinna@hotmail.com - ORCID: 0000-0002-2138-5849; itala_guimaraes@outlook.com - ORCID: 0000-0002-9253-2391

\begin{abstract}
The objective of this study was to evaluate the effect of a plant growth regulator (PGR; Stimulate ${ }^{\circ}$ ) on the yield and quality of zucchini fruits from plants of the cultivar Caserta-Italiana grown under different salinity levels of the irrigation water (SLIW). A randomized block design was used, in a $2 \times 6$ factorial arrangement consisted of two SLIW $\left(0.5\right.$ and $\left.5.0 \mathrm{dS} \mathrm{m}^{-1}\right)$ and six PGR application modes: imbibition of seeds for $8 \mathrm{~h}$ in distilled water (PGR-T1; Control); imbibition of seeds for $8 \mathrm{~h}$ in PGR at $10 \mathrm{~mL} \mathrm{~L}^{-1}$ (PGR-T2); imbibition of seeds for $8 \mathrm{~h}$ in PGR at $10 \mathrm{~mL} \mathrm{~L}^{-1}$ plus foliar application at $10 \mathrm{~mL} \mathrm{~L}^{-1}$ at the flowering stage (PGR-T3); imbibition of seeds for $8 \mathrm{~h}$ in PGR at $10 \mathrm{~mL} \mathrm{~L}^{-1}$ plus two foliar applications at the flowering stage and at 20 and 30 days after sowing (PGR-T4); foliar application at $10 \mathrm{~mL} \mathrm{~L}^{-1}$ at the flowering stage (PGR-T5); and two foliar applications at $10 \mathrm{~mL} \mathrm{~L}^{-1}$ at 20 and 30 days after sowing (PGR-T6). The SLIW affected differently the variables of the zucchini crops evaluated. The PGR application to plants under no salt stress $(0.5 \mathrm{dS} \mathrm{m})$ increased the solid soluble concentration and biomass accumulation of zucchini fruits. The PGR application as seed treatment and foliar application at the flowering stage increased the fruit yield of zucchini plants irrigated with saline water.
\end{abstract}

Key words: Cucurbita pepo, Cucurbitaceae, abiotic stress, salinity

\section{Produtividade e qualidade de abobrinha italiana em função da água salina e aplicação de bioestimulante}

RESUMO: Objetivou-se avaliar a utilização de bioestimulante (Stimulate ) na produtividade e na qualidade de frutos de abobrinha, cultivar Caserta Italiana, em condições salinas. O delineamento utilizado foi o de blocos casualizados, em esquema fatorial $2 \times 6$, sendo dois níveis de salinidade da água de irrigação $\left(0,5\right.$ e $\left.5,0 \mathrm{dS} \mathrm{m}^{-1}\right) \mathrm{e}$ seis estratégias de aplicação de bioestimulante [B1 - ausência de bioestimulante (embebição das sementes por 8 horas em água destilada); B2 - aplicado via tratamento de sementes (embebição por $8 \mathrm{~h}$ em bioestimulante); B3 aplicação via semente (embebição por 8 horas em solução de bioestimulante $10 \mathrm{~mL} \mathrm{~L}^{-1}$ ) mais uma aplicação foliar no florescimento $\left(10 \mathrm{~mL} \mathrm{~L}^{-1}\right)$; B4 - aplicação via semente (embebição por 8 horas em solução de bioestimulante $\left.10 \mathrm{~mL} \mathrm{~L}^{-1}\right)$ mais duas aplicações via foliar no florescimento aos 20 e 30 dias após a semeadura; B5 - aplicação foliar (10 $\left.\mathrm{mL} \mathrm{L}^{-1}\right)$ no florescimento; B6 - duas aplicações foliares $\left(10 \mathrm{~mL} \mathrm{~L}^{-1}\right)$, aos 20 e 30 dias após a semeadura]. A salinidade da água de irrigação afetou de forma diferenciada as variáveis analisadas na cultura da abobrinha. A aplicação do bioestimulante, na ausência do estresse salino, resultou no aumento do teor de sólidos solúveis e no acúmulo da biomassa de abobrinha. $O$ bioestimulante aplicado via sementes e durante o florescimento aumentou a produtividade de frutos de abobrinha irrigada com água salina.

Palavras-chave: Cucurbita pepo, cucurbitaceae, estresse abiótico, salinidade 


\section{INTRODUCTION}

Zucchini (Cucurbita pepo L.) is among the 10 vegetables with the highest economic value and yield in Brazil. It was the $26^{\text {th }}$ most marketed product in 2016 , with a volume of $42,710.70 \mathrm{Mg}$, with predominance of the variety Abobrinha Italiana (CEAGESP, 2018). In Brazil, $483.55 \mathrm{Mg}$ of fruits were marketed in the Northeast region of Brazil in 2017, reaching BRL (R\$) 753,386.37 (CEASA/CE, 2018).

This species is moderately tolerant to salinity, with limits at 3.1 and $4.7 \mathrm{dS} \mathrm{m}^{-1}$ for irrigation water and saturated extract, respectively (Ayers \& Westcot, 1999). However, its response to this abiotic stress varies according to the plant genotype and development stage, environmental factors, intensity and duration of the stress, cultural practices, irrigation management, and edaphoclimatic conditions (Strassburger et al., 2011; Balkaya et al., 2016).

Considering the need for the use of saline water in food production, the adoption of technologies that reduce the deleterious effect of this abiotic stress is needed. Therefore, researches have been developed using plant growth regulator (PGR) as a mitigating agent of effects of salt stress on sweet maize (Cunha et al., 2016), popcorn maize (Oliveira et al., 2016), cowpea (Oliveira et al., 2017), and gherkin (Cucumis anguria) (Souza Neta et al., 2018) crops. These researches show different results for the responses of these species to the application of PGR, denoting the need for more studies, mainly regarding the application mode.

Despite zucchini is classified as a moderately tolerant species to salinity, the use of irrigation with saline water and application of PGR can affect its plant growth and fruit yield and quality. Thus, the objective of this study was to evaluate the effect of different application modes of a PGR (Stimulate) on zucchini crops subjected to irrigation with saline water.

\section{Material ANd Methods}

The experiment was conducted at the experimental area of the Department of Agronomic and Forest Sciences (DCAF) of the Universidade Federal Rural do Semi-Árido (UFERSA),

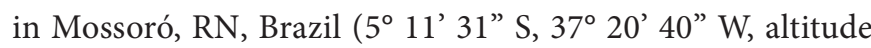
of $18 \mathrm{~m}$ ). The predominant climate of the region is BSwh', hot and dry, according to the Köppen classification, characterizing a semiarid tropical climate, with an irregular rainy season in the summer or autumn, concentrating in the first months of the year (Alvares et al., 2013).

Data of temperature, wind speed, air relative humidity, and rainfall depths during the experiment were obtained from the UFERSA Climatological Station, located at $2 \mathrm{~km}$ from the experiment site. The rainfall depths were evaluated for 10 days during the experiment period. The temperatures ranged from 24.63 to $28.15{ }^{\circ} \mathrm{C}$ (minimum), from 25.37 to $29.31{ }^{\circ} \mathrm{C}$ (maximum), and from 25.00 to $28.73{ }^{\circ} \mathrm{C}$ (mean), and presented mean of approximately $27.35^{\circ} \mathrm{C}$ throughout the crop cycle. The air relative humidity ranged from 63.69 to $86.38 \%$ (minimum), from 65.09 to $88.52 \%$ (maximum), and from 64.39 to $87.45 \%$ (mean).
A randomized block design with four repetitions was used, with a $2 \times 6$ factorial arrangement. The treatments consisted of two salinity levels of the irrigation water $\left(0.5\right.$ and $\left.5.0 \mathrm{dS} \mathrm{m}^{-1}\right)$, and six application modes of a plant growth regulator (PGR): imbibition of seeds for $8 \mathrm{~h}$ in distilled water (PGR-T1; Control); imbibition of seeds for $8 \mathrm{~h}$ in PGR $\left(10 \mathrm{mLL}^{-1}\right)$ (PGR-T2); imbibition of seeds for $8 \mathrm{~h}$ in PGR at $10 \mathrm{~mL} \mathrm{~L}^{-1}$ plus foliar application at $10 \mathrm{~mL} \mathrm{~L}^{-1}$ at the flowering stage (PGR-T3); imbibition of seeds for $8 \mathrm{~h}$ in PGR at $10 \mathrm{~mL} \mathrm{~L}^{-1}$ plus two foliar applications at the flowering stage and at 20 and 30 days after sowing (PGR-T4); foliar application at $10 \mathrm{~mL} \mathrm{~L}^{-1}$ at the flowering stage (PGR-T5); and two foliar applications at $10 \mathrm{~mL} \mathrm{~L}^{-1}$ at 20 and 30 days after sowing (PGR-T6). The plots consisted of three pots containing one plant each.

The PGR used (Stimulate ${ }^{\circ}$ ) was a liquid formulation composed of $50 \mathrm{mg} \mathrm{L}^{-1}$ of indole-3-butyric acid (auxin), $90 \mathrm{mg} \mathrm{L}^{-1}$ of kinetin (cytokinin), $50 \mathrm{mg} \mathrm{L}^{-1}$ of gibberellic acid (gibberellin), and $99.981 \%$ of inert ingredients (Castro \& Vieira, 2001).

Zucchini seeds of the cultivar Caserta-Italiana were sowed in 8-liter pots, using two seeds per pot. Thinning was carried out at the $15^{\text {th }}$ day after sowing to make the plants more vigorous. The soil (Ultisol) used as substrate was collected at the UFERSA campus. A 2.0-cm layer of coconut fiber was added to the top of the soil after sowing to maintain the soil moisture. The plants were grown in open field, with spacing of $0.7 \times 1.5 \mathrm{~m}$ between pots.

Two irrigation systems were used, one for each salinity level, composed of a 500-liter water box, a circulating pump run by a single-phase motor $(210 \mathrm{~V}, 60 \mathrm{~Hz})$, and lateral rows with microtube emitters with mean flow of $2.5 \mathrm{~L} \mathrm{~h}^{-1}$. A nutrient solution was included in the irrigation water, characterizing it as a fertigation.

The nutrient solution was formulated according to recommendations of Adams (1994), with the following nutrient concentrations: 8, 2, 4, 2, 1, and $1 \mathrm{mmol} \mathrm{L}^{-1}$ of $\mathrm{N}, \mathrm{P}, \mathrm{K}, \mathrm{Ca}, \mathrm{Mg}$, and $S$, respectively, and $35,19,21,4,0.9$, and $0.7 \mu \mathrm{mol} \mathrm{L}^{-1}$ of $\mathrm{Fe}, \mathrm{Mn}, \mathrm{B}, \mathrm{Zn}, \mathrm{Cu}$, and $\mathrm{Mo}$, respectively.

The water used for the preparation of the fertigation solutions was from the supply system of the UFERSA central campus; it presented the following characteristics: $\mathrm{pH}$ of 8.30,

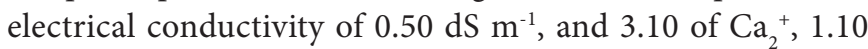
of $\mathrm{Mg}_{2}{ }^{+}, 0.30$ of $\mathrm{K}^{+}, 2.30$ of $\mathrm{Na}^{+}, 1.80$ of $\mathrm{Cl}^{-}, 3.00$ of $\mathrm{HCO}_{3}$, and 0.20 of $\mathrm{CO}_{3}^{2-}\left(\mathrm{mmolc} \mathrm{L}^{-1}\right)$.

The fruits were harvested at 49 days after sowing and evaluated for the following characteristics: number of fruits, obtained by manually counting the fruits of each plant that were in accordance to the minimum quality standards (not over ripened or withered, and without injury, rot, or damages by pests or viruses; CEAGESP, 2018); fruit yield, considering the fresh weight of the fruits of each plant; mean fruit weight, obtained by dividing the fruit yield by the number of fruits of each plant; fruit longitudinal and transversal diameters $(\mathrm{cm})$, measured with a manual caliper; pulp thickness, measured with a digital caliper (500-144B Mitutoyo, Aurora, USA) with resolution of 0.01 $\mathrm{mm}$; and pulp firmness, measured with a digital penetrometer (McCormick, Yakima, USA), with results obtained in lbf and converted to Newton (N) using the factor 4.45. 
The pulp firmness was determined and then the fruit pulp was sliced and processed in a domestic blender to obtain the juice, which was evaluated for soluble solids (SS), $\mathrm{pH}$, titratable acidity (TA), and SS to TA ratio (SS/TA).

SS was evaluated using a dropper plastic pipette to collect and deposit the juice in the prism of a digital refractometer (PR-1000; Atago, Tokio, Japan), and the results were expressed in ${ }^{\circ} \mathrm{Brix}$, as recommended by the AOAC (2012); $\mathrm{pH}$ was determined directly in the juice, using a digital $\mathrm{pH}$ meter (DMPH-2; Digimed, São Paulo, Brazil) calibrated in buffer solutions with $\mathrm{pH} 4.0$ and 7.0, according to the standards of the Adolfo Lutz Institute (Brasil, 2005); TA was determined by titration on 5 grams of juice diluted in $100 \mathrm{~mL}$ of distilled water with a standardized solution of sodium hydroxide at $0.1 \mathrm{~N}$, using phenolphthalein as indicator, according to the standards of the Adolfo Lutz Institute (Brasil, 2005), whose results were expressed in percentage; and SS/TA was determined by dividing SS by TA (Chitarra \& Chitarra, 2005).

The data obtained were subjected to analysis of variance, and significant means were subjected to the Tukey's test at $\mathrm{p} \leq 0.05$, using the Sisvar program (Ferreira, 2011).

\section{Results AND Discussion}

The analysis of variance showed that the interaction between the factors salinity levels of the irrigation water (SLIW) and plant growth regulator application modes (PGRAM) was significant for the number of fruits $(p \leq 0.01)$ and fruit yield ( $\mathrm{p} \leq 0.05)$, but not for fruit mean weight, transversal diameter, longitudinal diameter, and pulp thickness. The SLIW factors had significant isolate effects on mean fruit weight, fruit yield, and transversal diameter ( $\mathrm{p} \leq 0.01$ ); and the PGRAM had no significant isolate effect on any of the evaluated variables (Table 1).

The use of saline water for irrigation decreased the mean fruit weight in $25.15 \%$, and the transversal diameter in $8.93 \%$, when compared to those under irrigation with less saline water. However, it had no effect on fruit longitudinal diameter and pulp thickness, which presented means of 19.48 and $1.31 \mathrm{~cm}$, respectively (Table 1 ).
Mean fruit weight, transversal and longitudinal diameters, and pulp thickness presented no significant response to PGR$\mathrm{AM}$, presenting means of $539.77 \mathrm{~g}$ fruit $^{-1}, 7.27,18.48,19.48$, and $1.31 \mathrm{~cm}$, respectively.

The number of fruits was affected by SLIW according to the PGR-AM, with mean number of fruits 40.92, 37.50, and 47.71\% lower for the applications PGR-T1 (Control), PGR-T2, and PGR-T6, respectively (Table 2). Lower number of fruits in plants under salt stress was also found for other cucurbits, such as melon (Cordão Terceiro Neto et al., 2013) and pumpkin (Silva et al., 2014); these results are due to the increase of flower abortion rate caused by the decrease in quantity and viability of pollens (Ghanem et al., 2009).

The application of PGR as a seed treatment plus foliar application at $10 \mathrm{~mL} \mathrm{~L}^{-1}$ to zucchini plants at the flowering stage (PGR-T3) promoted the best results for growth and yield variables. Thus, PGR application as seed treatment and at the flowering stage is adequate to improve responses of zucchini plants to salt stress.

Table 2. Number of fruits and fruit yield in zucchini plants of the cultivar Caserta-Italiana as a function of salinity levels of the irrigation water and plant growth regulator (Stimulate) application modes

\begin{tabular}{|c|c|c|}
\hline \multirow{2}{*}{ PGR-AM } & \multicolumn{2}{|c|}{ Salinity (dS $\mathrm{m}^{-1}$ ) } \\
\hline & 0.5 & 5.0 \\
\hline \multicolumn{3}{|c|}{ Number of fruits } \\
\hline PGR-T1 (Control) & 3.25 Aab & $1.92 \mathrm{Bc}$ \\
\hline PGR-T2 & $4.00 \mathrm{Aa}$ & $2.50 \mathrm{Bbc}$ \\
\hline PGR-T3 & $2.50 \mathrm{Bb}$ & $4.00 \mathrm{Aa}$ \\
\hline PGR-T4 & 2.67 Aab & $2.50 \mathrm{Abc}$ \\
\hline PGR-T5 & $2.25 \mathrm{Bb}$ & 3.50 Aab \\
\hline PGR-T6 & $3.50 \mathrm{Aab}$ & $1.83 \mathrm{Bc}$ \\
\hline \multicolumn{3}{|c|}{ Fruit yield $\left(\mathrm{g} \mathrm{plant}^{-1}\right)$} \\
\hline PGR-T1 (Control) & $2005.41 \mathrm{Aa}$ & $856.11 \mathrm{Bb}$ \\
\hline PGR-T2 & $2168.12 \mathrm{Aa}$ & 1220.00 Bab \\
\hline PGR-T3 & $1649.37 \mathrm{Aa}$ & $1921.25 \mathrm{Aa}$ \\
\hline PGR-T4 & $1883.89 \mathrm{Aa}$ & 1118.75 Bab \\
\hline PGR-T5 & $1337.50 \mathrm{Aa}$ & $1359.58 \mathrm{Aab}$ \\
\hline PGR-T6 & $1978.12 \mathrm{Aa}$ & 1003.75 Bab \\
\hline
\end{tabular}

Means followed by the same letter in the columns are not different by the Tukey's test at $\mathrm{p} \leq 0.05$; PGR-AM - Plant growth regulator application modes; PGR-T1 (Control) Imbibition of seeds for 8 hours in distilled water; PGR-T2 - Imbibition of seeds for 8 hours in PGR at $10 \mathrm{~mL} \mathrm{~L}^{-1}$; PGR-T3 - Imbibition of seeds for 8 hours in PGR at $10 \mathrm{~mL} \mathrm{~L}^{-1}$ plus foliar application at $10 \mathrm{~mL} \mathrm{~L}^{-1}$ at the flowering stage; PGR-T4 - Imbibition of seeds for 8 hours in PGR at $10 \mathrm{~mL} \mathrm{~L}^{-1}$ plus two foliar applications at the flowering stage and at 20 and 30 days after sowing; PGR-T5 - Foliar application at $10 \mathrm{~mL} \mathrm{~L}^{-1}$ at the flowering stage; PGR-T6 - Two foliar applications at $10 \mathrm{~mL} \mathrm{~L}^{-1}$ at 20 and 30 days after sowing

Table 1. Analysis of variance for number of fruits (NF), mean fruit weight (MFW), fruit yield (FY), fruit transversal diameter (FTD), fruit longitudinal diameter (FLD), and fruit pulp thickness (PT) in zucchini plants of the cultivar Caserta-Italiana as a function of salinity levels of the irrigation water (SLIW) and plant growth regulator (Stimulate) application modes (PGR-AM), at 45 days after sowing

\begin{tabular}{|c|c|c|c|c|c|c|c|}
\hline \multirow{2}{*}{$\begin{array}{c}\text { Source } \\
\text { of variation }\end{array}$} & \multirow{2}{*}{ DF } & \multicolumn{6}{|c|}{ Mean square } \\
\hline & & $\overline{N F}$ & MFW & $\overline{F Y}$ & FTD & FLD & $\begin{array}{l}\text { PT } \\
\end{array}$ \\
\hline SLIW & 1 & $1.22^{\text {ns }}$ & $288041.72^{\star \star}$ & $4184250.19^{\star *}$ & $5.64^{\star *}$ & $18.96^{\text {ns }}$ & $0.028^{n s}$ \\
\hline PGR-AM & 5 & $0.79^{\text {ns }}$ & $5948.60^{\text {ns }}$ & $218217.08^{\text {ns }}$ & $0.84^{\mathrm{ns}}$ & $1.06^{\mathrm{ns}}$ & $0.028^{\mathrm{ns}}$ \\
\hline SLIW $\times$ PGR-AM & 5 & $4.01^{\star *}$ & $16215.27^{\text {ns }}$ & $694786.81^{*}$ & $0.81^{\mathrm{ns}}$ & $3.91^{\mathrm{ns}}$ & 0.029 ns \\
\hline Block & 3 & $0.63^{\text {ns }}$ & $32415.29^{\text {ns }}$ & $503642.96^{\text {ns }}$ & $1.05^{\mathrm{ns}}$ & $5.99^{\text {ns }}$ & $0.092^{\text {ns }}$ \\
\hline Residue & 33 & 0.47 & 13406.86 & 229862.97 & 0.59 & 5.44 & 0.025 \\
\hline CV $(\%)$ & 47 & 24.04 & 21.50 & 31.10 & 10.65 & 11.98 & 12.09 \\
\hline \multicolumn{2}{|c|}{ Mean test for salinity ( $d S \mathrm{~m}^{-1}$ ) } & & (g fruit $\left.{ }^{-1}\right)$ & & (cm) & (cm) & $(\mathrm{cm})$ \\
\hline \multicolumn{2}{|l|}{0.5} & & $615.97 \mathrm{a}$ & & $7.61 \mathrm{a}$ & $20.11 \mathrm{a}$ & $1.33 \mathrm{a}$ \\
\hline \multicolumn{2}{|l|}{5.0} & & $46.04 \mathrm{~b}$ & & $6.93 \mathrm{~b}$ & $18.85 \mathrm{a}$ & $1.28 \mathrm{a}$ \\
\hline
\end{tabular}

DF - Degrees of freedom; ns - Not significant, ${ }^{*}$ - Significant at $\mathrm{p} \leq 0.05$, and ${ }^{* *}$ - Significant at $\mathrm{p} \leq 0.01$ by the F test 
The fruit yield was significantly lower when using saline water without PGR (PGR-T1; Control), and in the treatments PGR-T2, PGR-T4, and PGR-T6, which represented losses of $57.31,43.73,40.61$, and $49.26 \%$, respectively. The treatments PGR-T3 (imbibition of seeds for 8 hours in PGR at $10 \mathrm{~mL} \mathrm{~L}^{-1}$ plus foliar application at $10 \mathrm{~mL} \mathrm{~L}^{-1}$ at the flowering stage) and PGR-T5 (foliar application at $10 \mathrm{~mL} \mathrm{~L}^{-1}$ at the flowering stage) were efficient to mitigate the effects of salt stress on the zucchini plants (Table 2).

The decrease in zucchini fruit yield as a function of the salinity level of the irrigation water was because of the decrease in number of fruits and the high flower abortion rate caused by the toxic effect of sodium ions $\left(\mathrm{Na}^{+}\right.$and $\left.\mathrm{Cl}^{-}\right)$. The effects of salt stress on fruit yield and quality are mainly due to its effect on leaf development, which decreases the plant photosynthetic capacity (Ramos et al., 2010), as already found for zucchini (Carmo et al., 2011; Strassburger et al., 2011) and melon crops (Cordão Terceiro Neto et al., 2013; Freitas et al., 2014).

Souza Neta et al. (2018) evaluated gherkin crops and found positive responses of fruit yield to PGR application, in plants irrigated with saline water.

The interaction between SLIW and PGR-AM was significant ( $\mathrm{p} \leq 0.05$ ) for solid soluble (SS) contents. The SLIW factor had isolate effects on fruit $\mathrm{pH}$ and titratable acidity (TA) at $\mathrm{p} \leq 0.05$, and on SS/TA and pulp firmness at $\mathrm{p} \leq 0.01$, and presented no significant effect on soluble solids (SS). The PGR-AM factor had no significant effect on any of the evaluated variables (Table 3 ).

The use of saline water for irrigation decreased the fruit $\mathrm{pH}, \mathrm{TA}, \mathrm{SS} / \mathrm{TA}$, and pulp firmness; the highest effect was found for SS/TA, which was $27.98 \%$ lower than that found for plants under irrigation with less saline water (Table 3 ).

These results are partly divergent from those reported by Medeiros et al. (2010), who evaluated cucumber (Cucumis sativus) plants and found increases in titratable acidity and decreases in pulp firmness as the salinity level was increased.

No significant response to the PGR-AM was found for fruit $\mathrm{pH}, \mathrm{TA}, \mathrm{SS} / \mathrm{TA}$, and pulp firmness, which presented means of $6.52,0.034 \%, 95.41$, and $35.48 \mathrm{~N}$, respectively. The fruit $\mathrm{pH}$ values were similar to those reported by Araújo et al. (2014), who found $\mathrm{pH}$ ranging from 6.5 to 6.7 for the same species; however, they found TA ranging from 0.8 to 0.12 , and SS/TA ranging from 40 to 60 , different from those found in the present study.
Few studies show information on the effect of the PGR Stimulate on chemical quality of zucchini fruits; however, studies on other species, such as grape vine (Vitis vinifera), have shown significant effects of PGR application on fruit quality (Camili et al., 2013), differing from the results found in the present study.

The SLIW had significant effect on the SS contents of the zucchini fruits without PGR application. The saline water increased the SS in 25.9\% (Table 4). Increases in SS in fruits as a function of SLIW have been reported for other cucurbit species, such as cucumber (Medeiros et al., 2010), melon (Pereira et al., 2017), watermelon (Costa et al., 2013) and gherkin (Morais et al., 2018). These increases in SS are usually due to their concentration caused by decreases in fruit size because of increases in concentration of sugars.

The results found for SS in the present study were different from those reported by Vendruscolo et al. (2017), who found that PGR application directly to the fruit increases SS content in melon fruits. These different results can be due to the species used and the PGR application mode. The treatment PGR-T1 (Control) resulted in higher SS ( $\left.{ }^{\circ} \mathrm{Brix}\right)$ contents under saline conditions; the SS of fruits under the other treatments was lower under the same conditions, which may indicate that PGR inhibits the absorption of the salts from the irrigation water.

Table 4. Mean solid soluble contents ( ${ }^{\circ}$ Brix) in fruits of zucchini plants of the cultivar Caserta-Italiana as a function of salinity levels of the irrigation water (SLIW) and plant growth regulator (Stimulate ${ }^{\circ}$ application modes (PGR-AM)

\begin{tabular}{|ccc|}
\hline \multirow{2}{*}{ PGR-AM } & \multicolumn{2}{c|}{ Salinity (dS m $\mathbf{~ m}^{-\mathbf{1}}$ ) } \\
\cline { 2 - 3 } PGR-T1 (Control) & $\mathbf{0 . 5}$ & $\mathbf{5 . 0}$ \\
PGR-T2 & $3.10 \mathrm{Ba}$ & $3.78 \mathrm{Aa}$ \\
PGR-T3 & $3.41 \mathrm{Aa}$ & $3.40 \mathrm{Aab}$ \\
PGR-T4 & $3.32 \mathrm{Aa}$ & $3.14 \mathrm{Ab}$ \\
PGR-T5 & $3.25 \mathrm{Aa}$ & $3.08 \mathrm{Ab}$ \\
PGR-T6 & $3.16 \mathrm{Aa}$ & $3.39 \mathrm{Aab}$ \\
\hline
\end{tabular}

Means followed by the same letter in the columns are not different by the Tukey's test at $\mathrm{p} \leq 0.05$; PGR-AM - Plant growth regulator application modes; PGR-T1 (Control) Imbibition of seeds for 8 hours in distilled water; PGR-T2 - Imbibition of seeds for 8 hours in PGR at $10 \mathrm{~mL} \mathrm{~L}^{-1}$; PGR-T3 - Imbibition of seeds for 8 hours in PGR at $10 \mathrm{~mL} \mathrm{~L}^{-1}$ plus foliar application at $10 \mathrm{~mL} \mathrm{~L}^{-1}$ at the flowering stage; PGR-T4 - Imbibition of seeds for 8 hours in PGR at $10 \mathrm{~mL} \mathrm{~L}^{-1}$ plus two foliar applications at the flowering stage and at 20 and 30 days after sowing; PGR-T5 - Foliar application at $10 \mathrm{~mL} \mathrm{~L}^{-1}$ at the flowering stage; PGR-T6 - Two foliar applications at $10 \mathrm{~mL} \mathrm{~L}^{-1}$ at 20 and 30 days after sowing

Table 3. Analysis of variance for solid soluble (SS), $\mathrm{pH}$, titratable acidity (TA), solid soluble to titratable acidity ratio (SS/TA), and fruit pulp firmness (FPF) in zucchini plants of the cultivar Caserta-Italiana as a function of salinity levels of the irrigation water (SLIW) and plant growth regulator (Stimulate) application modes (PGR-AM)

\begin{tabular}{|c|c|c|c|c|c|c|}
\hline \multirow{2}{*}{ Source of variation } & \multirow{2}{*}{ DF } & \multicolumn{5}{|c|}{ Mean square } \\
\hline & & SS & $\mathrm{pH}$ & $\overline{T A}$ & SS/TA & FPF \\
\hline SLIW & 1 & $0.14^{\mathrm{ns}}$ & $0.373^{*}$ & $0.001324^{\star}$ & $11563.19^{* *}$ & $252.97^{\text {** }}$ \\
\hline PGR-AM & 5 & $0.14^{\mathrm{ns}}$ & $0.005^{\mathrm{ns}}$ & $0.000069^{\text {ns }}$ & $466.75^{\text {ns }}$ & $16.96^{\mathrm{ns}}$ \\
\hline SLIW $\times$ PGR-AM & 5 & $0.21^{*}$ & $0.004^{\mathrm{ns}}$ & $0.000020^{\text {ns }}$ & $142.62^{\text {ns }}$ & $22.34^{\text {ns }}$ \\
\hline Block & 3 & $0.06^{\text {ns }}$ & $0.007^{\mathrm{ns}}$ & $0.000005^{\mathrm{ns}}$ & $71.94^{\text {ns }}$ & $23.01^{\text {ns }}$ \\
\hline Residue & 33 & 0.08 & 0.010 & 0.000034 & 225.90 & 16.04 \\
\hline CV $(\%)$ & 47 & 8.67 & 1.56 & 16.37 & 15.75 & 11.28 \\
\hline Mean test for salinity (dS $\mathrm{m}^{-1}$ ) & & & & $(\%$ of $A C)$ & & (N) \\
\hline 0.5 & & & $6.61 \mathrm{a}$ & $0.041 \mathrm{a}$ & $110.93 \mathrm{a}$ & $37.78 \mathrm{a}$ \\
\hline 5.0 & & & $6.43 b$ & $0.030 \mathrm{~b}$ & $49.89 \mathrm{~b}$ & $33.19 \mathrm{~b}$ \\
\hline
\end{tabular}

DF - Degrees of freedom; ns - Not significant, ${ }^{*}$ - Significant at $\mathrm{p} \leq 0.05$, and ${ }^{\star *}$ - Significant at $\mathrm{p} \leq 0.01$ by the F test 


\section{Conclusions}

1. The use of irrigation with water salinity of $5.0 \mathrm{dS} \mathrm{m} \mathrm{m}^{-1}$ decreases the fruit yield of zucchini plants of the cultivar Caserta-Italiana.

2. The plant growth regulator treatments with imbibition of seeds for 8 hours in PGR at $10 \mathrm{~mL} \mathrm{~L}^{-1}$ plus foliar application at $10 \mathrm{~mL} \mathrm{~L}^{-1}$ at the flowering stage (PGR-T3), and with foliar application at $10 \mathrm{~mL} \mathrm{~L}^{-1}$ at the flowering stage (PGR-T5) were efficient to mitigate the effects of salt stress on the zucchini plants.

3. The plant growth regulator application had no effect on the fruit quality of zucchini plants, regardless of the salinity of the irrigation water used.

\section{Literature Cited}

Adams, P. Nutrition of greenhouse vegetables in NFT and hydroponic systems. Acta Horticulturae, v.361, p.245-257, 1994. https://doi. org/10.17660/ActaHortic.1994.361.23

Alvares, C. A.; Stape, J. L.; Sentelhas, P. C.; Gonçalves, J. L. de M.; Sparovek, G. Koppen'sclimate classification map for Brazil. Meteorologische Zeitschrift, v.22, p.711-728, 2013. https://doi. org/10.1127/0941-2948/2013/0507

AOAC - Association of Official Analytical Chemistry. Official methods of analysis of association of official analytical chemists. 19.ed., Washington: AOAC. 2012. 3000p.

Araújo, H. S.; Cardoso, A. I. I.; Evangelista, R. M.; Takata, W. H. S.; Silva, E. G. Características físico-químicas de frutos de abobrinha-de-moita em função de doses de potássio em cobertura. Revista Colombiana de Ciências Hortícolas, v.8, p.242-249, 2014. https://doi.org/10.17584/rcch.2014v8i2.3217

Ayers, R. S.; Westcot, D. W. A qualidade de água na agricultura. 2.ed. Campina Grande: UFPB, 1999. 153p. Irrigação e Drenagem, 29

Balkaya, A.; Yildiz, S.; Horuz, A.; Doğru, S. M. Effects of salt stress on vegetative growth parameters and ion accumulations in cucurbit rootstock genotypes. Ekin Journal of Crop Breeding and Genetics, v.2, p.11-24, 2016.

Brasil. Métodos físico-químícos para análise de alimentos. 4.ed. Brasília: Agência Nacional de Vigilância Sanitária, 2005. 1000p.

Camili, E. C.; Rodrigues, J. D.; Ono, E. O. Giberelina, citocinina e auxina na qualidade química de bagas de uva 'Superior Seedless'. Bioscience Journal, v.29, p.1761-1770, 2013.

Carmo, G. A. do; Oliveira, F. R. A. de; Medeiros, J. F. de; Oliveira, F. de A.; Campos, M. de S.; Freitas, D. C. de. Teores foliares, acúmulo e partição de macronutrientes na cultura da abóbora irrigada com água salina. Revista Brasileira de Engenharia Agrícola e Ambiental, v.15, p.512-518, 2011. https://doi.org/10.1590/S141543662011000500012

Castro, P. R. de C. e; Vieira, E. L. Aplicações de reguladores vegetais na agricultura tropical. Guaíba: Livraria e Editora Agropecuária, 2001. 132p.

CEAGESP - Companhia de Entrepostos e Armazéns Gerais de São Paulo. Padrão mínimo de qualidade. Available on: <http://www. ceagesp.gov.br/produtos/abobrinha-italiana/>. Accessed on Ago. 2018.

CEASA/CE - Centrais de Abastecimento do Ceará S.A. Análise conjuntural. 2015. Available on: <http:// www.ceasa-ce.org.br/ index.php/análise-conjuntural>. Accessed on Ago. 2018
Chitarra, M. I. F.; Chitarra, A. B. Pós-colheita de frutas e hortaliças: Fisiologia e manuseio. 2.ed. Lavras: UFLA, 2005. 783p.

Cordão Terceiro Neto, C. P.; Gheyi, H. R.; Medeiros, J. F.; Dias, N. da S.; Campos, M. de S. Produtividade e qualidade de melão sob manejo com água de salinidade crescente. Pesquisa Agropecuária Tropical, v.43, p.354-362, 2013. https://doi.org/10.1590/S198340632013000400007

Costa, A. R. F. da; Medeiros, J. F. de; Porto Filho, F. de Q.; Silva, J. S. da; Costa, F. G. B.; Freitas, D. C. de. Produção e qualidade de melancia cultivada com água de diferentes salinidades e doses de nitrogênio. Revista Brasileira de Engenharia Agrícola e Ambiental, v.17, p.947-954, 2013. https://doi.org/10.1590/S141543662013000900006

Cunha, R. C. da; Oliveira, F. de A. de; Souza, M. W. de L.; Medeiros, J. F. de; Lima, L. A.; Oliveira, M. K. T. de. Ação de bioestimulante no desenvolvimento inicial do milho doce submetido ao estresse salino. Irriga, v.1, p.191-204, 2016. https://doi.org/10.15809/ irriga.2016v1n01p191-204

Ferreira, D. F. Sisvar: A computer statistical analysis system. Ciência e Agrotecnologia, v.35, p.1039-1042, 2011. https://doi.org/10.1590/ S1413-70542011000600001

Freitas, L. D. A.; Figueirêdo, V. B.; Porto Filho, F. de Q.; Costa, J. C. da; Cunha, E. M. da. Crescimento e produção do meloeiro cultivado sob diferentes níveis de salinidade e nitrogênio. Revista Brasileira de Engenharia Agrícola e Ambiental, v.18, p.20-26, 2014. https:// doi.org/10.1590/1807-1929/agriambi.v18nsupps20-s26

Ghanem, M. E.; Elteren, J. van; Albacete, A.; Quinet, M.; MartínezAndújar, C.; Kinet, J, M.; Pérez-Alfocea, F.; Lutts, S. Impact of salinity on early reproductive physiology of tomato (Solanum lycopersicum) in relation to a heterogeneous distribution of toxic ions in flower organs. Functional Plant Biology, v.36, p.125-136, 2009. https://doi.org/10.1071/FP08256

Medeiros, P. R. F. de; Duarte, S. N.; Dias, C. T. S.; Silva, M. F. D. Tolerância do pepino à salinidade em ambiente protegido: Efeitos sobre propriedades físico-químicas dos frutos. Irriga, v.15, p.301311, 2010. https://doi.org/10.15809/irriga.2010v15n3p301

Morais, D. L. de; Aroucha, E. M. M.; Oliveira, F. de A. de; Medeiros, J. F. de; Paiva, C. A. de; Nascimento, L. V. Impact of salinity on quality and post-harvest conservation of gherkin (Cucumis anguria L.). Journal of Agricultural Science, v.10, p.167-171, 2018. https://doi. org/10.5539/jas.v10n4p167

Oliveira, F. de A. de; Medeiros, J. F. de; Cunha, R. C. da; Souza, M. W. de L.; Lima, L. A. Uso de bioestimulante como agente amenizador do estresse salino na cultura do milho pipoca. Revista Ciência Agronômica, v.47, p.307-315, 2016.

Oliveira, F. de A. de; Oliveira, M. K. T. de; Lima, L. A.; Alves, R. de C.; Régis, L. R. de L.; Santos, S. T. dos. Estresse salino e biorregulador vegetal em feijão caupi. Irriga, v.22, p.314-329, 2017. https://doi. org/10.15809/irriga.2017v22n2p314-329

Pereira, F. A. de L.; Medeiros, J. F. de; Gheyi, H. R.; Dias, N. da S.; Preston, W.; Vasconcelos, C. B. e L. Tolerance of melon cultivars to irrigation water salinity. Revista Brasileira de Engenharia Agrícola e Ambiental, v.21, p.846-851, 2017. https://doi.org/10.1590/18071929/agriambi.v21n12p846-851

Ramos, S. R. R.; Lima, N. R. S.; Anjos, J. L. dos; Carvalho, H. W. L. de; Oliveira, I. R. de; Sobral, L. F.; Curado, F. F. Aspectos técnicos do cultivo da abóbora na região Nordeste do Brasil. Embrapa Tabuleiros Costeiros. Aracaju. 2010. 36p. Documento 154 
Silva, M. V. T. da; Lima, R. M. de S.; Silva, N. K. C.; Oliveira, F. L.; Medeiros, J. F. de. Produção de abóbora sob diferentes níveis de água salina e doses de nitrogênio. Revista Verde de Agroecologia e Desenvolvimento Sustentável, v.9, p.287-294, 2014.

Souza Neta, M. L. de; Oliveira, F. de A. de; Torres, S. B.; Souza, A. A. T.; Silva, D. D. A. da; Santos, S. T. dos. Gherkin cultivation in saline medium using seeds treated with a biostimulant. Acta Scientiarum. Agronomy, v.40, p.1-10, 2018. https://doi. org/10.4025/actasciagron.v40i1.35216
Strassburger, A. S.; Peil, R. M. N.; Fonseca, L. A.; Aumonde, T. Z.; Mauch, C. R. Crescimento e produtividade da abobrinha italiana: Efeito da concentração iônica da solução nutritiva. Semina: Ciências Agrárias, v.32, p.553-564, 2011. https://doi. org/10.5433/1679-0359.2011v32n2p553

Vendruscolo, E. P.; Rabelo, R. S.; Campos, L. F. C.; Martins, A. P. B.; Semensato, L. R.; Seleguini, A. Alterações físico-químicas em frutos de melão rendilhado sob aplicação de bioestimulante. Revista Colombiana de Ciências Hortícola, v.11, p.459-463, 2017. https://doi.org/10.17584/rcch.2017v11i2.7413 